\title{
Possibilidade de Transmissão de Fusarium solani f.sp. glycines, Agente Causal da Podridão Vermelha da Raiz da Soja, Através da Semente
}

\author{
Clarice R. Balardin ${ }^{1}$, Alisson F. Celmer ${ }^{1}$, Ervandil C. Costa ${ }^{1}$, Rosana C. Meneghetti \\ \& Ricardo S. Balardin ${ }^{1}$ \\ 'Departamento de Defesa Fitossanitária, Universidade Federal de Santa Maria, Camobi, Santa Maria, RS, \\ CEP 97111-970, Cx. Postal 5025, e-mail: rsbalardin@balardin.com.br
}

(Aceito para publicação em 13/06/2005)

Autor para correspondência: Ricardo Silveiro Balardin

BALARDIN, C.R., CELMER, A.F., COSTA, E.C. \& BALARDIN, R.S. Possibilidade de transmissão de Fusarium solani f.sp. glycines, agente causal da podridão vermelha da raiz da soja, através da semente. Fitopatologia Brasileira 30:574581. 2005.

RESUMO

Um isolado de Fusarium solani f.sp. glycines, coletado em plantas de soja (Glycine max) na região de Cruz Alta - RS, foi utilizado em experimentos conduzidos com o objetivo de avaliar a possibilidade de a semente ser um veículo eficiente de disseminação da podridão vermelha da raiz na cultura da soja. A transferência de propágulos do patógeno para sementes de soja, armazenada durante um, seis e 12 meses, foi realizada através da mistura de grãos de sorgo (Sorghum bicolor), solo e resíduos de colheita, previamente esterilizados e posteriormente infetados, em condições de laboratório, com F. solani f.sp. glycines. As evidências de que sementes de soja podem ser uma das fontes de inóculo primário de Podridão Vermelha da Raiz relacionaram-se à presença de clamidósporos aderidos externamente às sementes, após seis meses de armazenamento. As sementes apresentando crescimento do fungo após 12 meses de armazenamento, um mínimo de 75 unidades formadoras de colônias $/ \mathrm{ml} \mathrm{removidas} \mathrm{do} \mathrm{tegumento} \mathrm{das} \mathrm{sementes} \mathrm{de} \mathrm{soja} \mathrm{e} \mathrm{plântulas} \mathrm{formadas}$ a partir das sementes infetadas após 12 meses de armazenamento mostrando sintomas da doença.

Palavras-chave adicionais: Glycine max, semente, fungo, disseminação.

\begin{abstract}
Possible transmission of Fusarium solani f. sp. glycines, causal agent of Sudden Death Syndrome, through soybean seed

A Fusarium solani f.sp. glycines isolate collected in Cruz Alta - RS, Brazil, was utilized in these experiments to evaluate the possibility of the Sudden Death Syndrome (SDS) pathogen being transmitted by soybean (Glycine max) seeds. The seedborne nature of SDS pathogen was demonstrated using infected sorghum (Sorghum bicolor) seeds, infested soil, and infected plant debris as transport vehicles of inoculum. The following evidence of soybean seeds being the primary inoculum of SDS pathogen was chlamidospores were externally adhered to the soybean seeds after six months; soybean seeds had with the fungus mycelium after 12 months of storage; 75 c.f.u./ml were removed from the seed coat after 12 months of storage; and the fungus was transmissible after 12 months of storage.
\end{abstract}

Additional keywords: Glycine max, seed, fungus, dissemination.

\section{INTRODUÇÃO}

A podridão vermelha da raiz (PVR), causada por Fusarium solani (Mart.)Sacc. f.sp. glycines Roy, doença importante na cultura da soja [Glycine $\max ($ L.) Merrill], já foi identificada em todas as regiões produtoras do país (Embrapa, 1999). A velocidade com que o patógeno tem-se disseminado entre as regiões produtoras, no Brasil ou nas demais regiões produtoras do mundo, sugere que a semente pode ser um agente de disseminação de $F$. solani f.sp. glycines.

A transmissão de patógenos através das sementes pode ocorrer pela presença de esporos, estruturas de sobrevivência, ou resíduos de colheita contendo inoculo junto à semente (Nash \& Snyder, 1964; Baker, 1972; Neergaard, 1977; Scott \& Evans, 1984).
A importância dos clamidosporos como unidades de sobrevivência, infecção e disseminação tem sido demonstrada (Burkholder, 1919; Nash et al., 1961; Christou \& Snyder, 1962). Clamidosporos aderidos a sementes de feijão (Phaseolus vulgaris L.) germinam em até 16 h, o que não influencia o estabelecimento da patogênese (Cook \& Snyder, $1965)$ e não afeta a severidade de epidemias causadas por $F$. solani f.sp. glycines (Hall, 1996). Estas têm sido desencadeadas mesmo com uma baixa concentração de clamidósporos aderidos às sementes, mostrando que estes são elementos decisivos na patogênese, tanto pela sua capacidade de acompanhar as sementes (Nash \& Snyder, 1964) quanto pela persistência de F. solani f.sp. glycines no solo (Hall, 1996).

A probabilidade dos clamidosporos de $F$. solani f.sp. phaseoli, presentes em partículas de solo, serem 
transportados na massa de grãos e acarretarem infecção direta das sementes, devido ao desenvolvimento de micélio do patógeno nos tecidos do hospedeiro, foi relatada por Nash \& Snyder (1964).

A inibição na formação de clamidosporos no solo pode ser relacionada a altos níveis de nutrientes, e favorecida por déficits minerais ou fatores químicos diversos (Alexander et al., 1966). Resíduos de tecidos infetados de plantas são freqüentemente citados como os principais meios de introdução de patógenos através das sementes (Maude, 1996).

As estratégias de transmissão empregadas pelos patógenos nem sempre são aparentes, embora possam estar ligadas tanto à localização dos resíduos como à biologia do patógeno em estudo. Alguns dos fungos transmitidos dessa forma são Gaeumannomyces graminis (Sacc.) von Arx \& D. Olivier var. graminis, Ascochyta rabiei (Pass) Lab., Septoria linicola (Speg.) Garassini e S. apiicola (Speg) (Neergaard, 1977). O objetivo deste trabalho foi o de investigar a possibilidade de a semente de soja ser um meio de transmissão do agente da podridão vermelha da raiz.

\section{MATERIAL E MÉTODOS}

\section{Isolamento, cultivo e multiplicação de Fusarium solani f.sp. glycines}

O experimento foi realizado no laboratório de Fitopatologia do Departamento de Defesa Fitossanitária da Universidade Federal de Santa Maria - RS. Foi utilizado um isolado de $F$. solani f.sp. glycines, coletado em planta de soja, proveniente de uma lavoura na região de Cruz Alta -RS. Segmentos do colo das plantas, apresentando os sintomas de avermelhamento e esporulação azulada do patógeno, típico da Podridão Vermelha da Raiz, foram desinfestados com álcool (70\%), hipoclorito de sódio e três lavagens seqüenciais com água estéril. $\mathrm{O}$ cultivo do fungo foi realizado em meio de cultura batata-dextrose-ágar (BDA) + estreptomicina $(60 \mathrm{ppm})$. A incubação ocorreu em incubadoras do tipo B.O.D., regulada para uma temperatura de $20 \pm 2{ }^{\circ} \mathrm{C}$ e período luminoso de $12: 12 \mathrm{~h}$ (luz:escuro), sendo utilizada luz azul durante três a cinco dias. Para obtenção da cultura pura, foram transferidas pequenas porções do meio contendo micélio da borda das colônias em desenvolvimento para novas placas com BDA. O isolado purificado foi multiplicado sobre grãos de sorgo [Sorghum bicolor (L.) Moench] esterilizados. Para esterilização, os grãos de sorgo (200 g) foram embebidos em água durante $2 \mathrm{~h}$ em copos de Becker de 2.000 ml. Em seguida, o excesso de água foi removido e os grãos esterilizados, através de duas autoclavagens seqüenciais (121 ${ }^{\circ} \mathrm{C}$ ), cada uma com duração de 30 min. Os copos de Becker com os grãos foram resfriados à temperatura ambiente antes de serem inoculados com o fungo. Em cada copo foram adicionados dez blocos de $0,5 \mathrm{~cm}^{2}$ de micélio do fungo, e mantidos em incubação durante 15 a 20 dias sob temperatura de $20 \pm 2{ }^{\circ} \mathrm{C}$.
Preparo dos inertes e inoculação das sementes de soja

Grãos de sorgo infetados por $F$. solani f.sp. glycines foram empregados para inoculação dos materiais inertes (solo e resíduos de colheitas) utilizados como vias de disseminação e inoculação das sementes de soja. Foi considerado um tratamento testemunha, sem mistura de material às sementes. Antes de serem inoculados, os materiais inertes foram esterilizados através de duas autoclavagens seqüenciais $\left(121^{\circ} \mathrm{C}\right)$ cada uma com duração de $20 \mathrm{~min}$. A quantidade utilizada para inoculação de cada um dos materiais inertes obedeceu à proporção de 2,5 \pm 0,5\% de grãos de sorgo infetadas (p/p). A incubação dos materiais inertes ocorreu em incubadora com fotoperíodo de $12 \mathrm{~h}$ (luz azul:escuro) e temperatura de $20 \pm 2{ }^{\circ} \mathrm{C}$, durante um período de 30 dias.

Os experimentos foram executados com sementes com umidade de $12 \%$ da cultivar BR 16, armazenadas em caixas de papel (1 Kg) e em placas de Petri (34 g). Antes de serem misturadas aos materiais inertes, as sementes de soja foram tratadas com Pentacloronitrobenzeno (PCNB - 75\%) adicionado a $500 \mathrm{ml}$ de água/100 Kg de sementes. Os materiais inertes foram misturados às sementes nas proporções de 0,$0 ; 0,5 ; 1,0$ e $5,0 \%(\mathrm{p} / \mathrm{p})$, e estas foram mantidas em armazenamento para possibilitar contaminação concomitante do patógeno durante um período de até 12 meses. As sementes colocadas em caixas de papel (15 x 15 $\mathrm{x} 25 \mathrm{~cm}$ ) foram armazenadas sob condições que simulassem as da armazenagem comercial com temperatura em torno de $20 \pm 2{ }^{\circ} \mathrm{C}$ e $.50 \pm 10 \%$ de umidade. Por outro lado, as placas de Petri contendo $34 \mathrm{~g}$ foram armazenadas em incubadoras do tipo B.O.D. já que se constituíram em controles positivos para as sementes armazenadas em condições de armazém.

\section{Recuperação e quantificação do patógeno}

As avaliações foram realizadas depois de um, seis e 12 meses de armazenamento. Foram considerados o número de sementes com crescimento de F. solani f.sp. glycines, número de esporos e/ou clamidósporos associados externamente ao tegumento das sementes e o número de plantas com sintomas da doença, após o armazenamento.

$\mathrm{O}$ número de sementes mostrando crescimento de $F$. solani f.sp. glycines foi determinado através dos métodos do papel de filtro e plaqueamento direto em meio de cultura:

a) Papel de filtro: as sementes foram removidas das caixas de papel e amostradas aleatoriamente para serem colocadas em caixas de acrílico do tipo germbox, com 25 sementes/caixa e quatro repetições. As caixas foram incubadas em câmara apropriada com fotoperíodo de 12:12 h (luz azul:escuro), e temperatura de $22 \pm 2{ }^{\circ} \mathrm{C}$, durante um período de 15 dias. A avaliação da presença de sementes com crescimento visível de $F$. solani f.sp. glycines foi realizada após sete a dez dias de incubação, sendo que sua identificação foi baseada nas descrições de Roy et al. (1989) e Roy (1997).

b) Plaqueamento direto de sementes: realizado com 
sementes retiradas das caixas de papel e colocadas sem assepsia superficial em meio de BDA, incubadas em câmaras do tipo B.O.D. com fotoperíodo de 12:12 h (luz azul:escuro), e temperatura de $20 \pm 2{ }^{\circ} \mathrm{C}$ por 14 dias. Ao término do período de incubação, foi contado o número de sementes com crescimento do patógeno. Não foi realizada assepsia superficial das sementes para evitar que o inóculo estabelecimento superficial ou sub-superficialmente no tegumento fosse inviabilizado.

c) Determinação das unidades formadoras de colônias: a concentração de esporos e/ou clamidosporos aderidos ao tegumento das sementes foi obtida a partir da lavagem de amostras de $34 \mathrm{~g}$ de sementes armazenadas nas caixas de papel. As sementes, sem os materiais inertes infetados pelo patógeno, foram colocadas em balões volumétricos $(200 \mathrm{ml})$, contendo $20 \mathrm{ml}$ de uma solução de água destilada esterilizada mais Tween $80(0,5 \%)$, e mantidos em agitador mecânico durante 10 min. A suspensão obtida da lavagem das sementes foi diluída (dez vezes) para ser determinado o número de esporos e/ou clamidosporos e o número de unidades formadoras de colônias. $\mathrm{O}$ número de esporos e/ou clamidosporos de F. solani f.sp. glycines foi estimado com base na média de oito leituras realizadas em câmara de Neubauer.

O número de unidades formadoras de colônias (u.f.c.) foi obtido a partir da transferência de $1 \mathrm{ml} /$ placa da suspensão para placas de Petri contendo meio de cultura de Nash e Snyder modificado - MNSM (Cho et al., 2001). Este meio consiste de $20 \mathrm{~g}$ de ágar, $15 \mathrm{~g}$ de peptona, $1 \mathrm{~g}$ de $\mathrm{KH}_{2} \mathrm{PO}_{4}$, $0,5 \mathrm{~g}$ de $\mathrm{MgSO}_{4} \cdot 7 \mathrm{H}_{2}$. O meio foi autoclavado à $120^{\circ} \mathrm{C}$ por $20 \mathrm{~min}$, e após o resfriamento à $\pm 45{ }^{\circ} \mathrm{C}$, foi acrescentado $2,4 \mathrm{~g}$ de Pentacloronitrobenzeno - PCNB (75\%). As placas foram colocadas em incubação em câmaras do tipo B.O.D., com fotoperíodo de 12:12 h (luz azul:escuro), e temperatura de $20 \pm 2{ }^{\circ} \mathrm{C}$, durante três dias. No final do período de incubação, foi determinado o número de colônias de $F$. solani f.sp. glycines por placa e calculado o número de unidades formadoras de colônias.

A transmissibilidade do patógeno a partir das sementes armazenadas durante os 12 meses foi realizada através da semeadura das sementes em vasos de cerâmica (9 cm de diâmetro) com $180 \mathrm{ml}$ de substrato esterilizado. Os vasos foram mantidos em bandejas plásticas, com uma lâmina de água de aproximadamente $2 \mathrm{~cm}$ para manutenção do nível de umidade do solo compatível com a necessidade do patógeno, para causar a infecção nas plântulas de soja. Como controle, foram utilizados vasos com substrato esterilizado, sendo utilizados quatro grãos de sorgo infetados pelo patógeno para cada semente de soja. As condições de incubação foram ajustadas para um fotoperíodo de 12:12 h (luz do dia: escuro), temperatura de $18 \pm 2{ }^{\circ} \mathrm{C}$, durante 25 dias a partir da semeadura, ou até quando os sintomas das plantas controle (plantas inoculadas no momento da semeadura) mostraram-se evidentes. Ao término do período de incubação, foram considerados os sintomas foliares, sintomas no colo da planta, e no sistema radicular. Nas folhas os sintomas considerados foram clorose seguida de necrose internerval, formada a partir da margem das folhas. No colo e raízes foram considerados os sintomas de necrose. Quando foram observados os sintomas no colo e raízes, fragmentos das plântulas foram colocados em meio de cultura para confirmar a presença de $F$. solani f.sp. glycines.

\section{Análise dos dados}

Os dados envolvendo a possibilidade de transmissão do $F$. solani f.sp. glycines foram analisados através de métodos qualitativos de freqüência sendo considerado percentagem de sementes de soja com crescimento do patógeno, número de esporos e clamidósporos, número de u.f.c. e incidência de sementes infetadas pelo fungo. As análises qualitativas foram realizadas através do software Microsoft Excel 2000. Foram realizadas análises da variância (ANOVA) e de regressão. Foi utilizado o teste de Tukey (pd"0.05) para comparação de médias. Foi utilizado o software Plot It ambiente Windows 98 versão 3.20e (Scientific Programming Enterprises, Haslet, Michigan, 48840).

\section{RESULTADOS E DISCUSSÃO}

Os resultados obtidos neste trabalho demonstram a possibilidade de materiais inertes infetados pelo $F$. solani f.sp. glycines, acompanhando sementes de soja, transportarem inóculo e transmitirem eficientemente o patógeno causador da podridão vermelha da raiz da soja (PVR).

Os materiais inertes utilizados para avaliar a eficácia do transporte de inóculo para as sementes de soja mostraram diferença significativa. Grãos de sorgo foram eficientes no processo de transferência de inóculo de $F$. solani f.sp. glycines.

O volume de sementes considerado durante o armazenamento não influenciou os resultados obtidos, pois tanto as amostras ( $34 \mathrm{~g}$ ) mantidas em placas de Petri como aquelas mantidas em caixas de papel $(1 \mathrm{~kg})$ apresentaram resultados estatisticamente semelhantes, conforme dados apresentados (Tabelas 1 e 2).

No primeiro mês de avaliação, os resíduos de colheita infetados apresentaram percentagem de sementes infetadas significativamente superior aos demais materiais inertes. Solo infetado foi o material inerte que acarretou o menor número de sementes infetadas quando comparado aos demais inertes.

Com seis meses de armazenamento, foi observada redução acentuada no número de sementes infetadas por $F$. solani f.sp. glycines, independentemente do material inerte. Destaca-se que, grãos de sorgo e solo infetados, embora tenham apresentado menor número de sementes infetadas no primeiro mês de armazenamento, não apresentaram diferença significativa quanto à transferência de inóculo do patógeno para as sementes de soja ao $6^{\circ}$ e ao $12^{\circ}$ meses de armazenamento (Figura 1).

Após o $1^{\circ}$ mês de armazenamento, somente foram encontrados esporos na suspensão proveniente da lavagem 
TABELA 1 - Associação entre Fusarium solani f.sp. glycines e sementes de soja (Glycine max) misturadas a materiais inertes pré inoculados, e armazenadas por um e seis meses em placas de Petri. Santa Maria, resultados de lavagem de sementes (Cfu e Câmara de Neubauer). 2000

\begin{tabular}{|c|c|c|c|c|c|c|}
\hline \multirow[t]{2}{*}{ Tratamento } & \multicolumn{2}{|c|}{ Cfu (meses) } & \multicolumn{2}{|c|}{$\begin{array}{c}\text { Clamidosporos } \\
\left(\mathrm{X} \cdot \mathbf{1 0}^{4}\right)\end{array}$} & \multicolumn{2}{|c|}{$\begin{array}{l}\text { Esporos } \\
\left(\mathrm{X} .10^{4}\right)\end{array}$} \\
\hline & 1 & 6 & 1 & 6 & 1 & 6 \\
\hline Testemunha & 16,00 & & 0,00 & 0,00 & 0,00 & 0,00 \\
\hline Solo/ 0,5 & 218,00 & 148,00 & 0,00 & 1,50 & 0,00 & 1,00 \\
\hline Solo/ 1 & 211, & 15 & & 1,50 & 0,00 & 1,00 \\
\hline Solo/ 5 & 169,00 & 200,00 & 0,00 & 2,50 & 2,00 & 1,50 \\
\hline Sorgo/ 0,5 & 29,00 & & 0,00 & 0,50 & 0,00 & 0,50 \\
\hline Sorgo/ 1 & 256,00 & 33 & 0,00 & 1,00 & 0,50 & 0,50 \\
\hline Sorgo/ 5 & 281,00 & 116 , & 0,00 & 1,50 & 1,50 & 0,50 \\
\hline Res C & 760 & & & 1,50 &, 00 & 0,50 \\
\hline Res Col/ 1 & 1006 & 538,00 & 0,00 & 2,00 & 0,50 & 1,00 \\
\hline Res Col/ 5 & 1124,00 & 0,00 & 0,00 & 2,50 & 3,00 & 1,50 \\
\hline
\end{tabular}

de sementes de soja, não sendo encontrados clamidósporos. Estes resultados foram obtidos a partir da contagem de propágulos do F. solani f.sp. glycines em câmara de Neubauer. O número de esporos aumentou proporcionalmente ao aumento da proporção de material inerte e sementes de soja (Figura 2).

Ao sexto mês de armazenamento, foi observado um aumento no número de clamidósporos, independentemente do material inerte adicionado às sementes. Foi observada tendência crescente de aumento no número de clamidósporos quando foi utilizado resíduo de colheita como material inerte
TABELA 2 - Associação entre Fusarium solani f.sp. glycines e sementes de soja (Glycine max) misturadas a materiais inertes pré inoculados, e armazenadas por um e seis meses em caixas de papel (resultados de lavagem de sementes - Cfu e Câmara de Neubauer). Santa Maria, 2000

\begin{tabular}{|c|c|c|c|c|c|c|}
\hline \multirow[t]{2}{*}{ Tratamento } & \multicolumn{2}{|c|}{ Cfu (meses) } & \multicolumn{2}{|c|}{$\begin{array}{c}\text { Clamidosporos } \\
\left(\mathrm{X} \cdot 10^{4}\right)\end{array}$} & \multicolumn{2}{|c|}{$\begin{array}{l}\text { Esporos } \\
\left(X .10^{4}\right)\end{array}$} \\
\hline & 1 & 6 & 1 & 6 & 1 & 6 \\
\hline Testemunha & 9,00 & 2,00 & 0,00 & 0,00 & 0,00 & 0,00 \\
\hline Solo/0,5 & 137,00 & 179,00 & 0,00 & 2,00 & 0,60 & 0,75 \\
\hline Solo/1 & 121,00 & 159,00 & 0,00 & 1,00 & 1,40 & 1,13 \\
\hline Solo/5 & 299,00 & 50,00 & 0,00 & 1,38 & 4,80 & 0,38 \\
\hline Sorgo $/ 0,5$ & 506,00 & 68,00 & 0,00 & 1,63 & 6,30 & 0,50 \\
\hline Sorgo/1 & 136,00 & 140,00 & 0,00 & 5,63 & 6,40 & 1,38 \\
\hline Sorgo/5 & 875,00 & 733,00 & 0,00 & 4,75 & 6,30 & 10,13 \\
\hline Res $\mathrm{Col} / 0,5$ & 96,00 & 374,00 & 0,00 & 1,63 & 8,90 & 0,63 \\
\hline $\mathrm{Res} \mathrm{Col} / 1$ & 302,00 & 158,00 & 0,00 & 1,88 & 19,90 & 0,88 \\
\hline Res Col/5 & 2640,00 & 802,00 & 0,00 & 5,88 & 108,10 & 11,88 \\
\hline
\end{tabular}

(Figura 3). A concentração de esporos do fungo apresentou tendência decrescente acentuada, mesmo que no sexto mês de armazenamento ainda tenham sido coletados das sementes. Semelhante redução ocorreu com as u.f.c. no $6^{\circ}$ mês de armazenagem, quando foi considerado resíduo de colheita a 1 e $5 \%$ (Figura 4). Estes resultados demonstram uma redução na quantidade geral de inóculo do $F$. solani f.sp. glycines, acompanhado de aumento na quantidade de estruturas de sobrevivência.

Aos 12 meses de armazenamento, foi observada uma redução no número de clamidósporos aliada à ausência quase

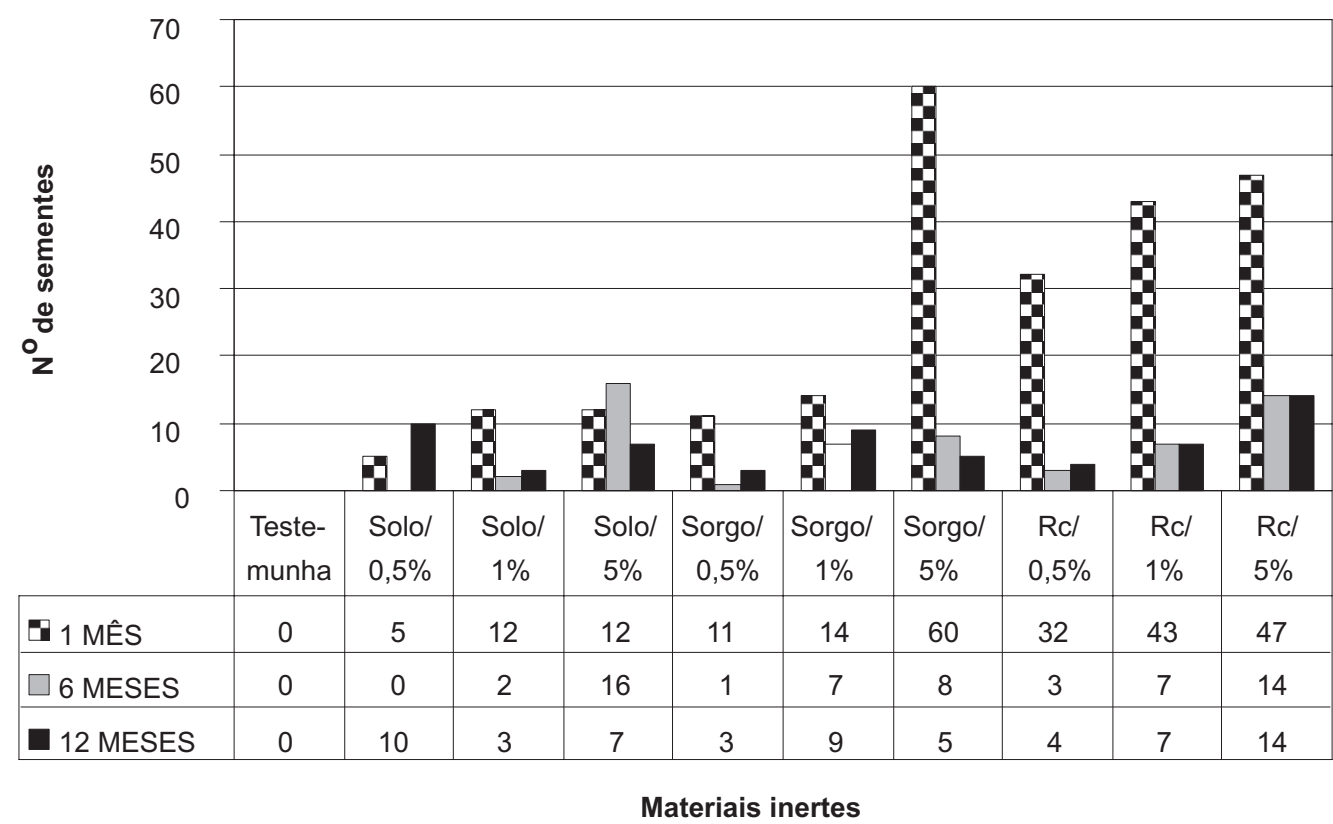

FIG. 1 - Número de sementes de soja (Glycine max) com crescimento de Fusarium solani f.sp. glycines após um, seis e 12 meses de armazenamento em caixas de papel $(1 \mathrm{~kg})$ e misturada aos materiais inertes (solo, grãos de sorgo e resíduos de colheita - Rc) na proporção de $0,5 \%, 1,0 \%$ e 5,0\%. 


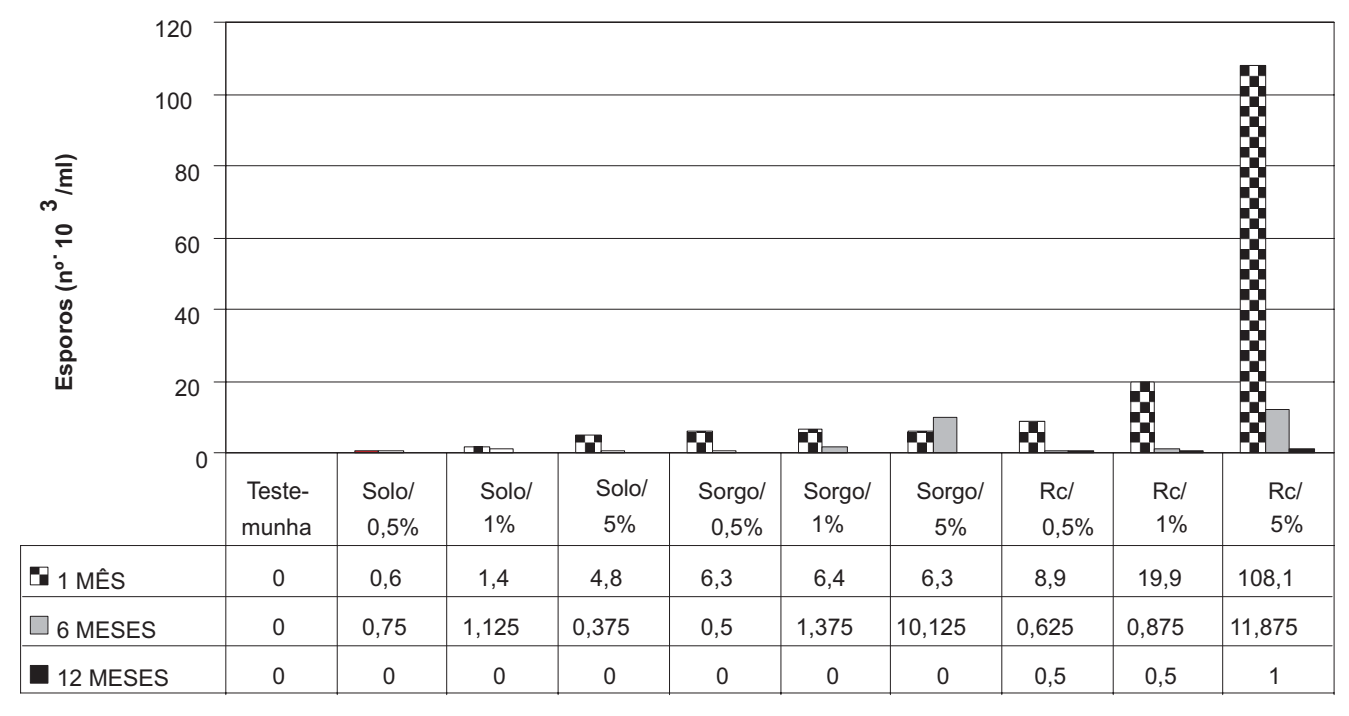

Materiais inertes

FIG. 2 - Número de esporos de Fusarium solani f.sp. glycines obtido a partir do líquido de lavagem de sementes de soja (Glycine max) após um, seis e 12 meses de armazenamento em caixas de papel $(1 \mathrm{~kg})$ e misturada aos materiais inertes (solo, semente de sorgo e resíduos de colheita - RC) na proporção de $0,5 \%$, $1,0 \%$ e $5,0 \%$.

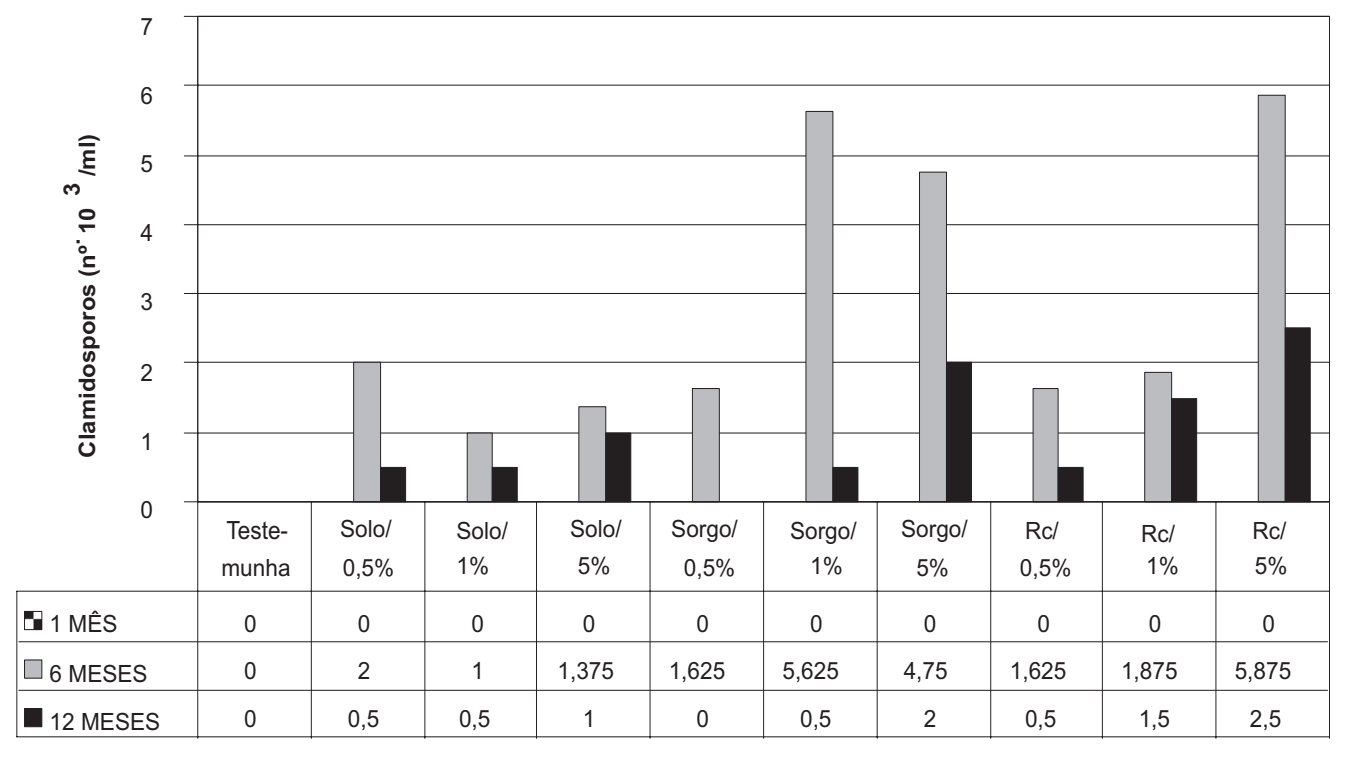

Materiais inertes

FIG. 3 - Número de clamidósporos $10^{3} / \mathrm{ml}$ de Fusarium solani f.sp. glycines obtido a partir do líquido de lavagem de sementes de soja (Glycine max) após um, seis e 12 meses de armazenamento em caixas de papel (1 $\mathrm{kg}$ ) e misturada aos materiais inertes (solo, semente de sorgo e resíduos de colheita - Rc) na proporção de $0,5 \%$, $1,0 \%$ e $5,0 \%$.

absoluta de esporos. Enquanto o número de esporos/ml sofreu uma redução acentuada desde o $1^{\circ}$ mês de armazenamento, o número de clamidósporos $/ \mathrm{ml}$ variou de zero no $1^{\circ}$ mês de armazenamento até $2,5 \cdot 10^{3} / \mathrm{ml}$ no $12^{\circ}$ mês. Aos seis meses de armazenamento foi observada a maior concentração de clamidósporos 5,88. 10³/ml (Figura 3).

A redução no número de esporos/ml, considerandose quaisquer dos materiais inertes testados, sugere que os 


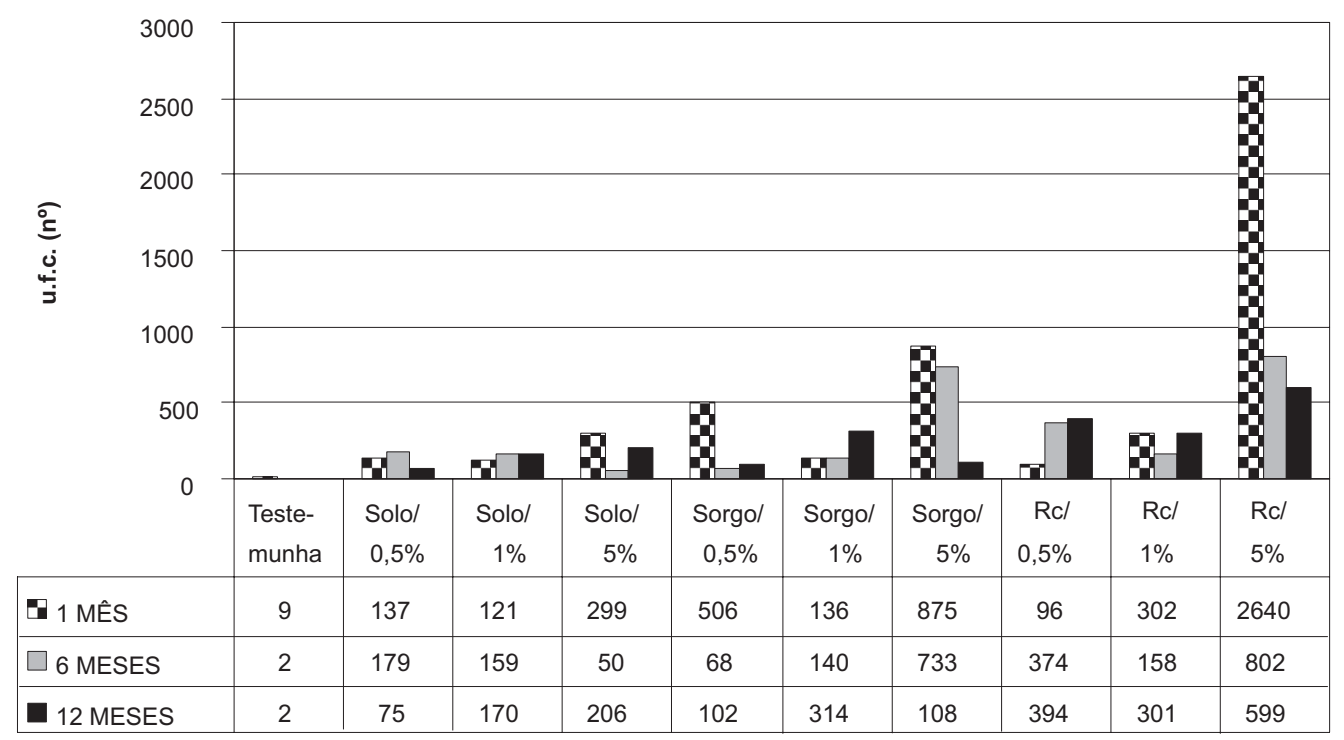

Materiais inertes

FIG. 4 - Número de unidades formadoras de colônias (u.f.c.) de Fusarium solani f.sp. glycines obtido a partir do líquido de lavagem de sementes de soja (Glycine max) após um, seis e 12 meses de armazenamento em caixas de papel (1 kg) e misturada aos materiais inertes (solo, semente de sorgo e resíduos de colheita - Rc) na proporção de $0,5 \%, 1,0 \%$ e $5,0 \%$.

esporos possuem limitada participação no transporte e transmissão do fungo através das sementes. Os resíduos de colheita foram mais eficazes em manter a viabilidade dos esporos do fungo no $1^{\circ}$ mês de armazenamento, mas após seis meses, foi observada redução no número de esporos do F. solani f.sp. glycines, o que é confirmado por Roy (1997), que observou que o armazenamento prolongado em meio BDA levou à redução na esporulação do fungo.

Na medida em que a formação de clamidosporos no solo é inibida por altos níveis de nutrientes e favorecida por déficits minerais ou fatores químicos diversos (Alexander et al., 1966), pode-se assumir que o rápido aumento na concentração de clamidósporos na superfície das sementes de soja deva-se ao meio pobre oferecido pelos inertes. Roy (1997) relatou a probabilidade de que partículas de solo, carregando clamidósporos sejam misturadas à massa de sementes durante a colheita e acarretem a contaminação das sementes.

A concentração de propágulos na superfície das sementes inoculadas com resíduos de colheita e armazenadas durante um mês aumentou consistentemente em relação à concentração de material inerte utilizada. É importante destacar, todavia, que embora os resíduos de colheita não tenham mantido a mesma tendência exponencial de crescimento, a concentração de propágulos aumentou quase 4x quando a concentração de inóculo foi de $0,5 \%$ do $1^{\circ}$ mês para o $12^{\circ}$ mês de armazenagem (Figura 4).

Os resultados obtidos, a partir da suspensão de propágulos coletada na lavagem de sementes, e considerando que foi observado alternância entre os macroconídios, predo- minantes após um mês de incubação e, de clamidósporos, predominantes após seis meses de incubação, levam a supor que o inóculo de $F$. solani f.sp. glycines pode ser transportado pelas sementes de soja na forma de clamidósporos aderidos externamente ao tegumento. Os esporos, devido à sua baixa longevidade aparentemente não apresentam importância no processo de transporte e transmissão de $F$. solani f.sp. glycines (Figura 2).

Dentre os inertes testados, os resíduos de colheita mostraram-se como os mais propícios para transporte e longevidade do inóculo. Entretanto, da mesma forma como todos os materiais inertes, entre o $6^{\circ}$ e o $12^{\circ}$ mês, foi observada redução na quantidade de propágulos do fungo aderidos externamente às sementes. Foi constatada a recuperação de F. solani f.sp. glycines mesmo quando os materiais inertes foram misturados às sementes na concentração de $0,5 \%$ (Figura 5). Em função da reprodução dos sintomas em plântulas de soja a partir das sementes armazenadas durante 12 meses ficou caracterizada a transmissão da PVR.

Os resultados obtidos considerando a presença de clamidósporos aderidos externamente às sementes de soja mesmo aos doze meses de armazenamento, a recuperação de $F$. solani f.sp. glycines das sementes armazenadas e a transmissão do fungo após 12 meses de armazenamento, são evidências de que as sementes de soja podem ser fontes de inóculo primário da PVR. Os resíduos de colheita e as partículas de solo podem efetivamente transferir inóculo de $F$. solani f. sp. glycines, quando em contato com sementes de soja.

A transmissibilidade do $F$. solani f. sp. glycines ao 


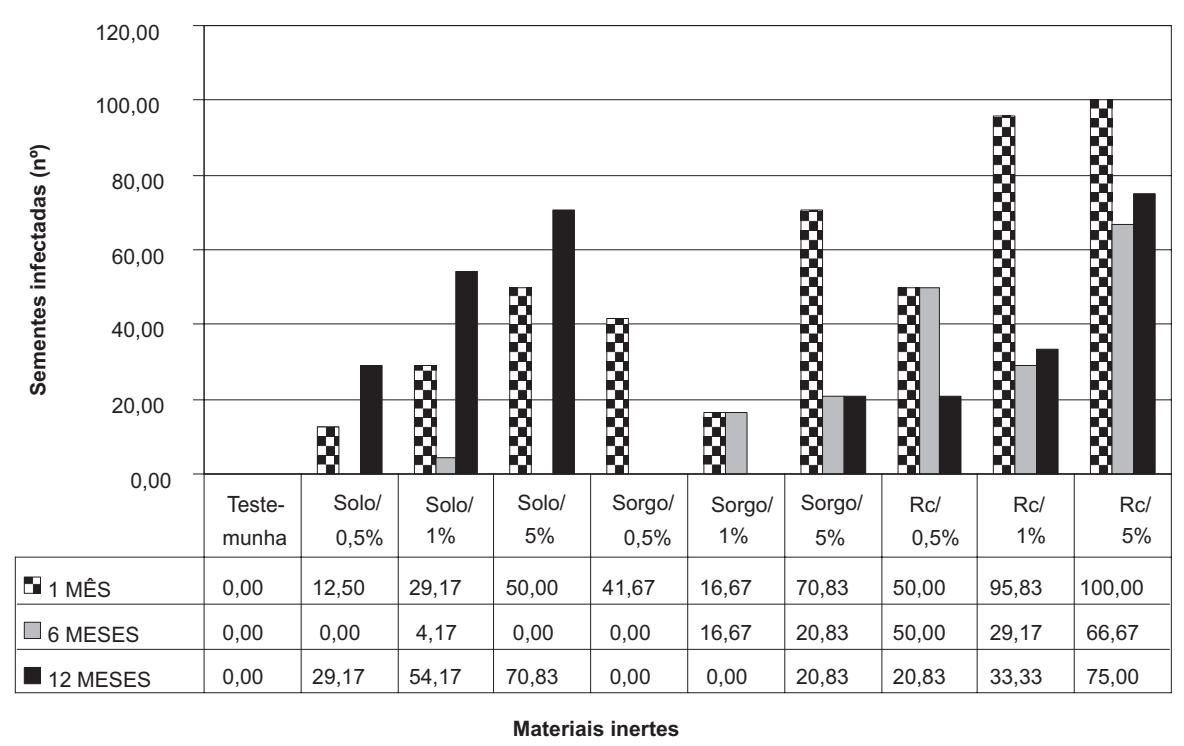

FIG. 5 - Incidência de sementes de soja (Glycine max) infetadas por Fusarium solani f.sp. glycines obtido através do plaqueamento de semente de soja em meio BDA, após um, seis e 12 meses de armazenamento em caixas de papel $(1 \mathrm{~kg})$ e misturada aos materiais inertes (solo - S, semente de sorgo - Sg e resíduos de colheita - Rc) na proporção de $0,5 \%, 1,0 \%$ e $5,0 \%$.

término do período de armazenagem confirmou a possibilidade de $F$. solani f.sp. glycines ser transmitido pela semente. Os sintomas foliares (Figura 6) e no colo da planta (Figura 7) foram avaliados. Os resultados sugerem que o $F$. solani f.sp. glycines dissemina-se em sementes de soja através de clamidosporos aderidos externamente ao tegumento. Mesmo na concentração de $0,5 \%$ de material inerte inoculado e misturado à semente foi observado crescimento do patógeno qualificando a semente como uma importante fonte de inóculo primário da PVR.

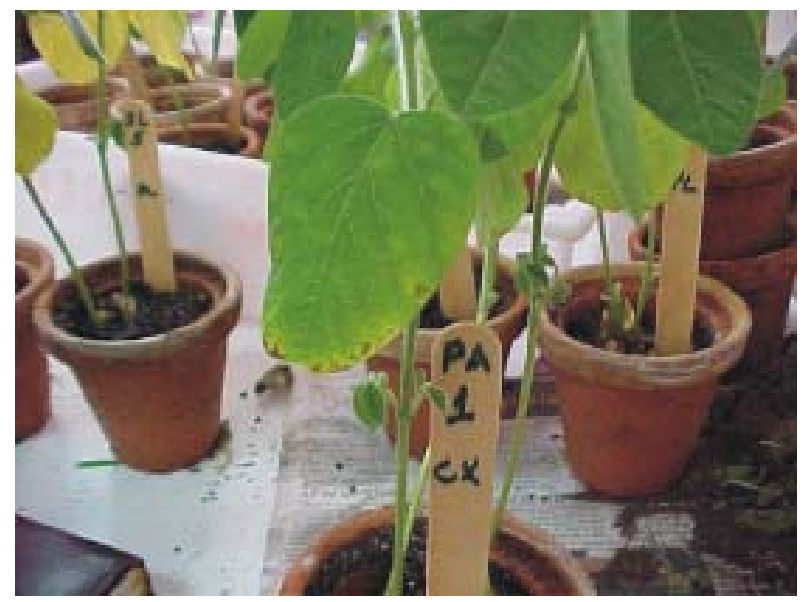

FIG. 6 - Transmissão de Fusarium solani f.sp. glycines a partir de sementes de soja (Glycine max) armazenadas com resíduos de colheita na proporção de $1,0 \%$.

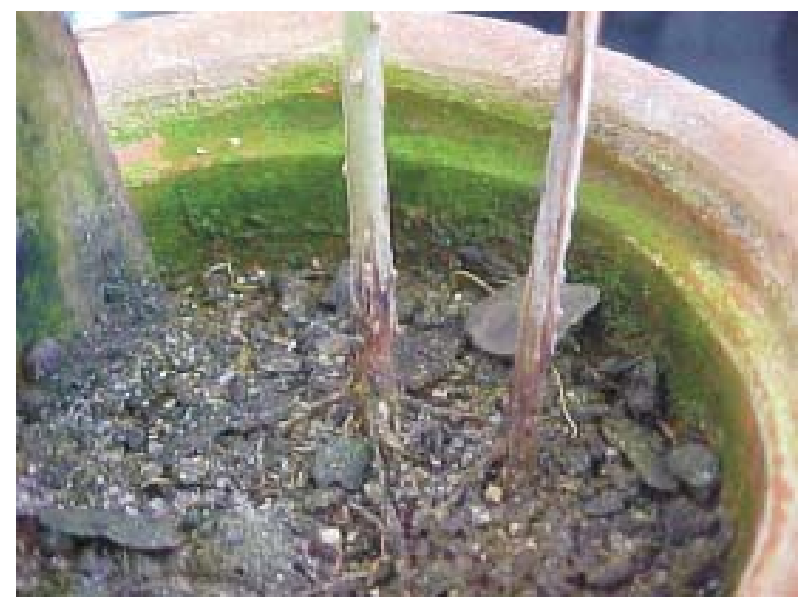

FIG. 7 - Sintomas causados por Fusarium solani f.sp. glycines no colo da plântula de soja (Glycine max).

\section{REFERÊNCIAS BIBLIOGRÁFICAS}

ALEXANDER, J.V., BOURRET, J.A., GOLD, A.H. \& SNYDER, W.C. Induction of chlamydospore formation by Fusarium solani in sterile soil extracts. Phytopathology 56 353-354. 1966.

BAKER, K.F. Seed Pathology. In: Kozlowski, T.T. (Ed.) Seed Biology. Vol. 2. Academic Press, New York. 1972. pp.317-416.

BURKHOLDER, W.H. The dry root-rot of the bean. Cornell Univ. Agric. Exp. Sta. Mem. 26:999-1033. 1919.

CHO, J.H., RUPE, J.C., CUMMINGS, M.S. \& GBUR, E.E. Isolation and identification of Fusarium solani f. sp. glycines from 
soil on modified Nash and Snyder's Medium. Plant Disease 85:256-260. 2001.

CHRISTOU, T. \& SNYDER, W.C. Penetration and host - parasite relationships of Fusarium solani f. phaseoli in the bean plant. Phytopathology 52:219-226. 1962.

COOK, R.J. \& SNYDER, W.C. Influence of host exudates on growth and survival of germlings of Fusarium solani f. phaseoli in Soil. Phytopathology 55:1021-1025. 1965.

EMBRAPA SOJA. Recomendações Técnicas para cultura da soja na região Central do Brasil 1999/2000. Londrina: 1999. 226. (Embrapa Soja). Documento, 132; Embrapa Agropecuária Oeste,5.

HALL, R. Inoculum Dynamics of Fusarium solani f. sp. phaseoli and Management of Fusarium root rot of Bean. In: Hall, R. (Ed). Principles and practice of managing soilborne plant pathogens. APS. 1996. pp.280-310.

MAUDE, R.B. Seedborne Diseases and their Control; principles \& practice. New York, CAB international, 1996.

MICROSOFT EXCEL. Microsoft Corporation. Versão 2000 para
Windows

NASH, S.M. \& SNYDER, W.C. Dissemination of the root rot Fusarium with bean seed. Phytopathology 54:880. 1964.

NASH, S.M., CHRISTOU, T. \& SNYDER, W.C. Existence of Fusarium solani f. phaseoli as chlamydospores in soil. Phytopathogy 51:308-12. 1961.

NEERGAARD, P. Seed Pathology. vols. 1 \& 2. London, Macmillan. 1977.

PLOT IT 3.20. Scientific Programming Enterprises. Haslet, Michigan, 48840. Versão para Windows.

SCOTT, S.W. \& EVAM, D.R. Sclerotinia of Sclerotinia trifoliorum in red clover seed. Transaction of the British Mycological Society 82:567-569. 1984.

ROY, K.W., LAWRENCE, G.W., HODGES, H.H., MCLEAN, K.S. \& KILLEBREW, J.F. Sudden death sindrome of soybean: Fusarium solani as incitant and relation of Heterodera glycines to disease severity. Phytopathology 79:191-197. 1989. 